\title{
Correction to: The Placenta and Plasmodium Infections: a Case Study from Blue Nile State, Sudan
}

\author{
Samia A. Omer ${ }^{1}$ (D) Suad M. Sulaiman ${ }^{2}$ \\ Published online: 17 October 2020 \\ (C) Springer Nature Switzerland AG 2020
}

\section{Correction to: Current Tropical Medicine Reports https://doi.org/10.1007/s40475-020-00214-1}

The article The Placenta and Plasmodium Infections: a Case Study from Blue Nile State, Sudan, written by Samia A. Omer and Suad M. Sulaiman, was originally published electronically on the publisher's internet portal (currently SpringerLink) on October 03, 2020, with open access. With the author(s)' decision to step back from Open Choice, the copyright of the article changed on October 16, 2020, to @ Springer Nature Switzerland AG 2020, and the article is forthwith distributed under the terms of copyright.

The original article has been corrected.

Publisher's Note Springer Nature remains neutral with regard to jurisdictional claims in published maps and institutional affiliations.

The online version of the original article can be found at https://doi.org/ $10.1007 / \mathrm{s} 40475-020-00214-1$

Samia A. Omer

samiaelhaj150@gmail.com

1 Department of Immunology and Biotechnology, Tropical Medicine Research Institute, National Centre for Research, Khartoum, Sudan

2 Sudan Medical Heritage Foundation, Khartoum, Sudan 